\title{
Analysis on the Essential Attribute of Tourism Poster
}

\author{
Mengmeng Zhou \\ Yantai Nanshan University \\ Yantai, China 265713
}

\begin{abstract}
The "imagination" and "alienation" in Lacan's mirror stage theory relevantly explain the reason why people are attracted by the poster. In the theory the "imitation" nature of human appropriately explain the reason why the poster information is accepted by people. At the same time, the "dependency" in the theory revealed that the information of poster still existed in the mind of consumers even if viewers are separated with the poster (viewers have accessed to the information of poster). The interaction between information and viewers still exists when they are separated. Tourism posters stimulate consumers' desire to buy through the planned spread of information, and ultimately achieve the goal of stimulating consumption. Tourism posters persuade and guide consumers to accept the information of poster actively, and achieve the purpose of corporate propaganda.
\end{abstract}

Keywords-Lacan's mirror stage theory; tourism poster; essential attribute

\section{TO TRIGGER CONSUMING DESIRE}

Before access to the information of tourism poster, consumers may have no desire to buy the target product. The tourism poster stimulates target consumers visually, persuade and guide them to buy. After a series of penetrating guidance, consumers may generate purchasing behavior.

Good tourism poster can help enterprises to establish a good image, open up production and marketing channel and increase competition ability, so it plays a crucial role for the survival and development of enterprise. At the same time, it also can strengthen the market economy, spread the economic information, evolve a system of production, supply and sales under normal operation and continuous development and promote the perfection of social economy. Tourism poster can guide public consumption, create fashion, enrich the contents of public life, and improve the life quality of the public. In addition to its economic function, tourism poster also is widely used in various fields of social life to spread scientific and cultural information and beautify people's mind and life.

\section{A. Information Spreading}

Tourism poster shall be combined with marketing activities, and with the ultimate goal to persuade consumers to buy the advertised products or enjoy the advertised service. In short, tourism poster is a kind of commercial behavior with selling goods and gaining profit as the ultimate goal. Tourism poster shows target consumers the nature, quality, functions and advantages of the goods, moves and persuades consumers, and influences and changes consumers' attitudes and behavior, and finally reaches the goal of selling goods out. Tourism poster is different from general promotion activities. In promotion activities, sellers directly show products to buyers, and exchange with consumers face to face. For tourism poster, the content of the poster persuades consumers to consume. The ultimate goal of persuasion is to sell the product out. All information of tourism poster shall be valuable to the public, so that it can play the role of spreading information, guiding consumption and meeting the needs of consumers.

Tourism poster is a purposed and planned information spreading method. At the same time, tourism poster shall pay a certain economic cost, and have specific media and open publicity tools. In order to achieve a certain goal and have a certain return, enterprises often regard the invested capital as investment. For example, machines, factories, warehouses and other facilities are regarded as investment, and their values depreciate to a certain percentage with the extension of time. Not all capitals invested in tourism poster can produce immediate sales effect, so the majority of merchants regard the cost of tourism poster as business expenses. With the formation and development of modern tourism poster concept, more and more people regard tourism poster as corporate investment behavior.

From the point of value creation, the investment effect of tourism poster generally is reflected by two aspects. One is consumption value. It depends on the consumption effect of tourism poster. Namely, consumers receive poster information, have a sense of identity on it and actively purchase. The other is the production value of tourism poster. It depends on the realization of consumption value. Tourism poster shall first satisfy the demands of consumers and then realize its targeted marketing and profit. Especially for commodity poster, the production purpose can only achieved by the realization of commodity sales. If treat tourism poster activities as investment, the requirements and views on tourism posters will change naturally. From the point of investment, tourism poster shall pursue the combination of long-term interests and immediate interests. It is a behavior with an eye on the future. It has certain risk and certain predictability.

Tourism poster is the product of the development of commodity economy. Its spread has a far-reaching impact and high penetration on entire social economic life, and subtle guiding and promotion function on people's consumption concept and consumption behavior. Therefore, it has an important significance to discuss and research the consumption guidance of tourism poster, its penetration to consumers' vision and mind, to construct a complete and scientific tourism 
poster spreading concept and promote the healthy development of tourism poster and communication industry.

Tourism posters give consumers a certain shock in a unique way, at the same time, attract their attention. For example, the logo of Apple Inc. is "an apple that has been taken a bit", which may make people think of Apple's innovative spirit of "rather to die honorably, not to live dishonorably". In fact, this spirit of innovation is the characteristic of Apple.

\section{B. Information Communication}

Communication is the exchange of thought under information transfer in order to reach some consensus. Different from deliverance, communication is a two-way activity, rather than a one-way influencing process from one side to the other side. Merchants deliver the information of tourism poster to target consumers through the mass media to persuade and induce consumers to buy the advertised products. Only when target consumers accept the information of tourism poster, or when consumers consider that the information of tourism poster is true and credible, and agree on the transmission ideas of the poster, can the information of tourism poster comes into play and achieves the process of communication. The communication function of tourism poster is different from the face-to-face interpersonal communication. Communication object is a group of consumers with same needs or same characteristics, rather than individual consumers. Tourism poster is not just an ordinary communication, but a persuasive communication. Its purpose is to influence consumers' brand attitude and purchase behavior, guide and persuade consumers to buy the advertised products on the poster. However, it is a very complex and arduous task to influence people's attitude and behavior. In order to finish this task, merchants should not only enable target consumers receive the information of tourism posters but also take some persuasive means to make target consumers accept the information of poster. And finally consumers are desired to buy the advertised products on the tourism poster.

Tourism poster is a bridge of the production and marketing, a maker of consuming desire and an "invincible salesmanship" of enterprise. Tourism poster is an important propaganda means of products. If merchants do not run propaganda, they themselves know what they are running. But consumers don't know what they are running. A motto of Coca Cola says: "success lies in propaganda". Tourism poster is a powerful means to promote the transformation of individual labor into social labor. It is conducive to the realization of the buying and selling of goods and service, and the transformation of individual value into social value, thus completing the "breathtaking jump" from commodities to service and currency. Therefore, tourism posters play a vital role in the survival and development of enterprises.

1) "Imagination" and persuasion": When consumers see tourism poster, the tourism poster may persuade consumers to identify the products. In other words, consumers may accept the information of tourism poster. The imitation function is resulted from "imagination". At the same time, consumers may cover their split with poster information (the disagreed part of poster information) in order to keep a surface completeness and consistency with products. At this time, consumers alienate themselves. Self struggle of consumers gradually disappear. They are persuaded by the poster, and generate the purchase behavior.

Tourism posters gradually affect the attitude of consumers, change their original attitude, and persuade consumers to like and buy the advertised products in the spread of commodity information, and arouse emotional resonance.

Tourism poster vigorously advertises for the real purchase behavior and the wonderful effect of the products or after consumption, which gives consumers a clear demonstration role, and guide consumers to purchase the products. In the guidance, tourism poster inform consumers of the use of product, method of application, and after-sale service in order to reduce consumers' doubts and attract more consumers to buy the products.

2) Changing from passive receiving into active acceptance: The organism has the ability to identify itself with outside image. When consumers receive the poster information, the information of poster make consumers identify with poster information. The poster information is penetrated into the vision of consumers. At this time, consumers are in a passive receiving state.

When consumers further understand the poster information the strength of self identity is enhanced, and the poster information is penetrated into the customers' mind. At this time, the passive receiving changes into the active acceptance.

Tourism posters impress consumers' psychology in the emotional way and arouse emotional resonance. On this basis, consumers generate a sense of trust further. The poster copywriting of the famous brand SK-II, subordinate to Procter $\&$ Gamble, is a clear proof. Its copywriting says "making you 12 years younger', which is a wonderful statement in the world of tourism posters. At this moment consumers are not considering the compound on the production line, but the beautiful self-image that the product can bring them. The comment of tourism poster on the brand may be exaggerated, but the important is that it represents the aspirations and inner evaluation of consumers to a certain extent. Thus, the spread of information can be recognized and accepted by consumers.

\section{TO STIMULATE CONSUMPTION}

Stimulating consumption is the ultimate goal of tourism posters. Poster can create a good consumption atmosphere. In the spread of information it can stimulate consumers' consuming desire and arouse their emotional resonance.

What is desire? Lacan held that desire was not a simple subconscious demand of one's inner heart, but a symbolic power formed in the language communication of people, and continuously updated in the language interaction with others. It is an important component constituting the internal structure of language discourse. It is a basic "signifier" and a needful experience of people that others cannot force them to express. It doesn't face real objects, but signifies and expresses a lack or shortage of ontological meaning in an alienation way. 
Therefore, Lacan said "desire is not the happiness in seeking satisfaction or a demand for love, but the result of the former from the later. It is the split phenomenon itself". Obviously, Lacan included the subjective "desire" into complex "relationship difference", so that desire becomes the element of interpersonal relations and social networks, and thus is associated with the language activity in social life. The "desire" in Lacan's theory is not the result of the subconscious inner requirement of main subject. It is formed in exchanging with others, in social application of language, and influenced and stimulated by others except for the main subject, according to the operating rule of symbolic signs.

To stimulate purchase desire is to stimulate consumers' potential need desire through tourism poster, and thus promote consumers to buy the products that can satisfy their psychological or physiological needs. This process, in fact, is a process to persuade consumers to buy. In order to make consumers generate purchase desire, "what benefits can the products bring to us" is the key for tourism poster to pursue. That is to say, the poster shall explain the characteristics of the goods standing on the consumers' grounds.

The purpose of stimulating the desire is not only aimed at consumers' mind but also their feelings. This is very important for the tourism poster. All tourism posters should strive to appeal people's desire.

The theory of mirror stage tells us that the biological world likes to seek similar things like themselves to prove their existence. When consumers receive the poster information, they will naturally extract information identical with their own personality, psychology and other factors from the poster information, and resonate with the information of tourism poster. To seek resonation starts stimulating visual nerves. When consumers receive the information of tourism poster, they may produce a visual mirror with the information of tourism poster. In other words, consumers identify the information of tourism poster as another self, or resonate with the information of tourism poster through self alienation, and finally seek self identity.

Most tourism posters will not simply focus on the immediate interests. It is more important to bring a greater development space for enterprise. At the early stage of investment, poster may not bring a great benefit for enterprise. But if merchants can resist using good posters, these posters will influence viewers' vision and bring considerable gains.

\section{TO ESTABLISH A CORPORATE IMAGE}

A good corporate image will enhance the employees' sense of honor and sense of belonging, and bring a strong cohesion for the enterprise. A good corporate image is a kind of wealth, which is of great attraction. The brand image is an intangible asset that is difficult to be valued. It is far beyond its own value. It has a clear advantage in the social life and production competition. For example, an enterprise with good image can give sufficient confidence for her consumers, and attract social capital and find reliable raw materials supplier and other good partners. A good corporate image is a large amount of intangible asset. It can greatly promote the development of enterprise under "favorable human condition". Whether the corporate image is good or bad plays a decisive role in the survival of enterprise.

The corporate image is a comprehensive reflection of product constituent elements in people's mind, such as the impression of product value, commodity property and product marks on people, as well as the subjective comment of people on enterprise. In the business operating mode, the products and services of enterprise are the key. Only by managing products and services well, can an enterprise establish a good corporate image.

Tourism posters will make enterprise more deeply and more timely feel the external pressure, and force enterprises to adopt new technologies and equipment, strengthen management, accelerate the upgrading of products and enhance the competition consciousness. Not all tourism posters are successful. And they are not omnipotent. Enterprises shall improve their production level and the quality of products and service to use posters to deliver information. Therefore, poster has played an important and positive role in improving the overall production level and management level and the corporate image.

\section{REFERENCES}

[1] He Xingqing, Hu Yunquan. Modern Management Psychology. Shenyang: Liaoning People's Publishing House, 1988: 23-47; 22-58.

[2] Wang Guancheng. Consumer Psychology. Beijing: Publishing House of Electronics Industry, 2004: 55-59.

[3] Lacan. Lacan Anthology. Shanghai: Translation Press, 2001.

[4] Fukuhara Taira. Translated by Wang Xiaofeng. Mirror Stage. Shijiazhuang: Hebei Education Press, 2002. 